\title{
Nullity and Other Defects of Administrative Decisions in the Czech Republic
}

\author{
Kateřina Frumarová \\ Faculty of Law, \\ Palacký University in Olomouc \\ Tř. 17 listopadu 8, \\ Olomouc 771 11, Czech Republic \\ E-mail: katerina.frumarova@upol.cz
}

\begin{abstract}
This article deals with the issue of administrative decision, which represents one of the principal forms of the realization of public administration in the Czech Republic. Even if the Czech legislation provides for its issuance a number of requirements in relation to its content and form, in practice, however, there are violations of these legal conditions and requirements and then we talk about a defective administrative decision. According to how to remedy the defective administrative acts, distinction is made between formally defective administrative decisions, factually inaccurate decisions, unlawful decisions, and next to them, separately null administrative decisions. The main attention is paid to the nullity, because only the nullity represents the most serious and also irremovable defect of an administrative decision. As the null decision does not exist from the perspective of law, it is not able to affect the rights and duties of its recipients. The null acts, as the only category of defective administrative acts, constitute an exception to the principle of the presumption of validity and correctness of administrative acts.
\end{abstract}

Keywords: administrative decision, defects of administrative decisions, factually inaccurate decisions, formally defective administrative decisions, nullity, presumption of correctness and validity, unlawful decisions 


\section{Introduction: administrative decisions and the principle of the presumption of their correctness and validity}

In general, the administration represents an intentional activity when each purposive activity should always lead to the realization of intended results and to meeting determined targets. That is why also the public administration-as a realization of executive power in the state-represents an activity focused on the administration of public affairs in the public interest that is realized as a law obligation imposed on competent authorities. One of the principal forms of the realization of public administration represents the issuance of administrative decisions. Moreover, public administration in the Czech Republic performs its tasks and goals by using other legal forms of action: especially through the issuance of subordinate legislation or measures of a general nature, through entering into a public contract or carrying out other acts (such as statements, certificates or notifications).

An administrative decision itself represents a result in the application process realized by public administrative bodies; it is a one-sided, authoritarian act of law application. An administrative body shall, by its decision, create, alter or abolish rights or duties of a particular person, or it shall declare in a certain case that such a person has or does not have rights or duties, or it shall decide on procedural issues in cases stipulated by the law. That decision-as a manifestation and result of a public power-must meet all the requirements set by legal order (cf. Art. 2, Para. 3 of the Constitution of the Czech Republic (1992) and Art. 2, Para. 2 of Charter (Resolution of the Presidium..., 1993)). ${ }^{1}$ A decision must always be issued by a competent administrative body as a result of a legal procedure and it must fulfill all statutory requirements of the content and form. ${ }^{2}$ On the other hand, we must realize that the more the activity of public administration is determined by laws, the more there is possibility and probability that the administrative body will be in contradiction with the legislation and with the requirements set by the law.

1 It is a basic and widely recognized requirement for the performance of public administration in any state governed by the rule of law, see Hofmann et al. (2011, p. 151) who state: "The public administration must act under and within the law, whether as contained in primary and secondary legislation or in the jurisprudence of competent courts". Similarly see, e.g., Wade \& Forsyth, 2009, p. 17; Adamiak \& Borkowski, 2009, pp. 32-33; Singh, 2001, p. 66; Schwarz, 2006.

2 We can then distinguish between competence, content, formal and procedural requirements decisions, see e.g., Hendrych et al., 2012, p. 204 et seq.; Sládeček, 2013, pp. 121-122; Chróścielewski \& Tarno, 2009, p. 140; Council of Europe, 1996, p. 13 et seq.; Potash, P. \& Hašanová, 2012, p. 210. 
The concept of an administrative decision is understood similarly in other countries. Slovak administrative law defines it as a decision in a certain case when the administrative bodies apply legal rules to individual cases and when they decide on the rights and duties of individuals (Vrabko et al., 2012, p. 199). In Poland, the administrative decision means "one-sided, authoritative expression of the will of a public authority, issued on the basis of a generally binding legal regulations concerning a certain external recipient, which decides his or her individual thing, issued under the Administrative Code and fulfilling the form and structure prescribed by the procedural law" (Kędziora, 1989, p. 248). In Germany, the administrative doctrine defines (in connection with $\S 35$ of VwVfG) administrative decisions (Verwaltungsakt) as "any regulation, decision or other sovereign measures (1), which makes office (2) in the field of public law (3) in order to cause external legal effects (4) in individual cases (5)" (Lehmann, 2002, p. 81). The Austrian legislation does not define the concept of decision (Bescheid) and the doctrine defines it as an authoritarian, formal decree of an administrative office addressed to individually designated persons which creates, alters or abolishes rights or duties or authoritatively declares them (Horáková et al., 2011, p. 105). In contrast, in the French law, the concept of decision (décision) is a more general and broader term which includes two basic groups: normative decisions (décisions réglementaires), known as regulations (the source of law) and then individual decisions (décisions individuelles), which relate to namely designated subjects (Chavrier, Delamarre \& Paris, 2010, p. 138 et seq).

If a situation arises when an administrative decision does not satisfy any of the conditions which are prescribed for them by legal order, we can talk about a defective administrative decision. Generally, a defective administrative act can be identified as an act of a public authority which has a legal deficiency or deficiencies, that is, one that does not match the complex of all legal rules regulating its creation and issuance. It is necessary to emphasize in this context that a defective administrative decision is defective because it has legal deficiencies, not because it is unjust or it does not reflect any other non-legal values. The primary purpose of the legislation in each state is to ensure that each individual administrative decision will be flawless. Yet in practice, of course, it happens that public administrative bodies make errors during the process of application of legal norms, which is reflected in a defect of an administrative act. The Czech administrative doctrine and case law try to clearly identify, categorize and describe these defects (Hoetzel, 1934, p. 268).

The problem of defective administrative decisions is not purely a problem of a legal theory, without a major practical importance. Conversely, a defective administrative decision and the nature of its defects is essential from the 
perspective of the recipient of such an act: it is particularly the question of the proper selection and application of legal means to protect and defend against such a defective act. In addition, of course, a defect of an administrative decision is also important for public authorities, whether in the context of the review of such an act, or in its performance (execution); not forgetting the possible liability for damages and non-pecuniary damage arised due to defective administrative decisions. And, finally, we can not overlook the possibility of prejudice to the rights of third parties, particularly with regard to their good faith in the regularity and legality of the exercise of public power (including public administration), which is reflected primarily in the principle of the presumption of correctness and validity of administrative acts.

This principle means that the administrative act is to be regarded as flawless until the opposite is officially found. It is a rebuttable legal presumption (praesumptio iuris tantum) of the validity and correctness of a decision, up until the contrary is proved. Therefore, a decision that is defective is valid and may come into force and be executed, until it is rid of the validity by a competent authority (until it is changed or canceled). Besides, the Czech Code of Administrative Procedure (2004, § 73, Para. 2) is clear: a legally effective decision shall be binding on participants and on all administrative bodies. But one essential exception to this principle applies: this principle does not apply to null decisions, to those which suffer the most serious defects (for more details see below).

The above principle of correctness and validity of administrative acts is not valid only in the Czech Republic (see, e.g., Chróścielewski \& Tarno, 2009, p. 141; Ochendowski, 2001, p. 183; or Singh, 2001, pp. 80-84). The principles of legal certainty and the protection of legitimate expectations can be found in the legal systems of many countries, although their precise legal content may partially differ from system to system (Craig, 2006, p. 607). However, in general, public administrative bodies must always respect the legitimate expectation that private individuals have in relation to the activities performed by these authorities, including the issuance of administrative decisions. The principle of legal certainty is also one of the fundamental principles of European Union law. Therefore, the presumption of validity is also applied to the decisions issued by the institutions of the European Union (Commission v. BASF, etc. [1994]; Shell v. Commission [1992], or Commission v. Greece [1988]). This presumption provides that decisions are legitimate and have legal effects, even if they suffer from a defect, up until they are canceled (Commission v. BASF, etc. [1994]).

One of the main aims of the paper is generally to define and characterize the institute of defective administrative decisions, and especially to categorize 
these defects and outline the possibilities of defense of the addressees against these acts. Another essential goal is to define in detail the most serious defect of administrative decisions - nullity - and, with regard to existing legislation, case law and doctrine, to describe the possibilities of protection against null acts which guarantee the Czech legal order and then evaluate it in comparison with foreign countries and their solutions to this problem. At the same time it is always necessary - in relation to administrative decisions and their possible defects - to take into account whether and to what extent some sphere should or should not be regulated by the state (and by administrative law) and what are the legitimate expectations of the citizens in this direction.

\section{Defects of administrative decisions}

Defects of administrative decisions can be categorized from different points of view. We can distinguish between defective administrative decisions according to the criterion of which sources of administrative law a given decision violateswhether it violates a constitutional, statutory or sub-statutory rules. Following the distinction between substantive law and procedural law, we can distinguish between formal defects and material defects. We can talk about formal defects if the defect of a decision is based on the breach of a rule of a procedural nature. In contrast, we can talk about material defects if the substantive legal rules are violated. From the viewpoint of the severity of the defects we can distinguish between null decisions (non-existent) and defective, but existing decisions, which enjoy the presumption of validity and correctness. According to how to remedy the defective administrative acts, a distinction is made between formally defective decisions, factually inaccurate decisions, unlawful decisions, and next to them, separately null administrative decisions (Skulová et al., 2012, p. 207 et seq). To remedy each of these defects, different legal means must be used but null decisions occupy a specific position: the remedy is not possible in any way (see below for more details).

\section{Formally defective administrative decisions}

The least serious defects that administrative decisions may have are the obvious mistakes in the writing of a decision. The obvious mistakes mean obvious clerical errors in the preparation of a written decision, when such mistake should be 
detectable by comparing the data or word with its correct use in documentation and materials for the issuance of a decision-these are the contents of the administrative file (Průcha, 2013, p. 208).

An example of such a defect is the absence of a date of the issuance of decision (The Supreme Administrative Court, 2011) or typing errors in the name or surname of the parties (The Supreme Administrative Court, 2008a or 2009), or even situations where the identity of the parties is incorrectly transcribed from a foreign language. Or it can also be a situation when a decision contains incorrect or incomplete name of the administrative body which issued the decision (The Supreme Administrative Court, 2006), or a situation when there is no impression of an official stamp on decision (The Supreme Administrative Court, 2007).

Such mistakes in the writing of a decision can be corrected whenever (even after its coming into force) by the administrative body which issued the decision, both upon the request of a participant and ex officio. The correction shall be made in the form of an amending decision or an amending resolution, depending on what part of the writing of the administrative decision shall be corrected. If the correction applies to a statement in the holding of the decision, the administrative body shall issue an amending decision. If the correction applies to a statement in another part than the holding of the decision (i.e. the reasoning or the notice), administrative body shall correct it in the form of an amending resolution. The right to lodge an appeal against the amending decision or amending resolution shall be possessed only by a participant who may be directly affected thereby. The object of the appeal, however, may only be a change made through that correction; fundamentally it does not target other issues, respectively other defects of the decision.

\section{Factually incorrect decisions}

In these cases there are decisions which are in accordance with the law, but they can be reproached for incorrectness (not illegality) in the approach and consideration of the matter that is the object of proceedings (Mazanec, 1996, p. 76 et seq.; Potěšil, 2006, p. 51). Usually, the "incorrectness (inaccuracy)" is understood as the inappropriateness, uselessness, inefficiency, insensitivity or injustice. This defect is then connected primarily to administrative acts, which are issued with the use of the administrative discretion. If the administrative body decides within the certain boundaries resulting from the administrative discretion, then, if its decision is not optimal, it does not mean that the law is violated. 
This defect quite often occurs in connection with administrative decisions concerning various administrative offenses, specifically in relation to the question whether the sanction was imposed at a reasonable (and not only legal) level. If the penalty corresponds to the legal requirements and range (from-to), it is not an unlawful decision, but there may be a factually incorrect decision. There may be cases where sanctions do not reflect the personal and property circumstances of the offender, the seriousness of the offense, etc. (The Supreme Administrative Court, 2010)

The defense and remedy of such a defect is in the hands of the addressees of the decision, on the basis of filing an appeal against such a defective act. The recipient must argue that defect in the appeal. According to Section 89, Paragraph 2 of the Code of Administrative Procedure, the appellate administrative body shall review the compliance of the challenged decision and relating proceedings always with the legal regulations - that is, without regard to the objections raised by the appellant. Conversely, the correctness of the challenged decision shall be reviewed only within the scope of objections contained in the appeal or otherwise only if so required by the public interest (Code of Administrative Procedure, § 89, Para. 2).

\section{Unlawfulness of an administrative decision}

Unlawful decisions constitute a further and, in practice, probably the largest group of administrative decisions. Unlawfulness in general means that the decision is contrary to the objective law. The principle of legality represents - in relation to any authoritative exercise of public power by public administrative bodies - the fundamental postulate and condition for its realization. ${ }^{3}$ The fundamental basis in this regard is Article 2, Paragraph 3 of Constitution and Article 2, Paragraph 2 of the Charter, according to which the state power may be asserted only in cases and within the bounds provided for by law and only in the manner prescribed by law. The principle of legality is also expressly enshrined in the Code of Administrative Procedure as one of the so-called basic principles of activities of administrative bodies, which represent the fundamental principles for the whole public administration performance in any democratic state governed by the rule of law. And the most important principle can undoubtedly be considered the principle of legality enshrined in Section 2, Paragraph 1 of the Code of

3 This principle is fundamental for the performance of public administration in other countries, see, e.g., Wade \& Forsyth, 2009, pp. 17-18; Schønberg, 2000, p. 7. 
Administrative Procedure. This principle implies that an administrative body shall act in accordance with laws and other legislative instruments as well as international treaties which constitute a part of the Czech legal order. At the same time, we can add that the principle of legality is one of the basic principles of good governance, thus principles that represent a summary of the requirements for a fair and responsive public administration and that essentially seek to protect the individual rights of the addressees of public administration, although their scope may be wider (Skulová, 2012, pp. 53-54). Also within the European Union, the fundamental importance of the principle of legality is consistently pointed out: "The public administration must act under and within the law, whether as contained in primary and secondary legislation or in the jurisprudence of competent courts" (Hofmann, Rowe \& Türk, 2011, p. 151).

An administrative decision is defective and unlawful, for example, in a situation when it is non-reviewable because of absence of reasons for the decision (The Supreme Administrative Court, 2003 or 2004a), or because the facts of the matter which the administrative authority took as the grounds for the contested decision are contrary to the documents or are not supported by them, or the case was incorrectly assessed from the perspective of substantive law, or when administrative authority exceeded the legally defined bounds of discretionary power, or abused it (The Supreme Administrative Court, 2004b).

In connection with unlawful administrative decisions, it should be stressed that in spite of their defects - that is, unlawfulness - they enjoy a presumption of validity and correctness. Until such a decision is changed or canceled by the competent authority, it needs to be seen as a perfect decision, with all of the resulting legal consequences. The remedy of an unlawful administrative act can be initiated both upon the request of a participant and ex officio. In the case of a decision, which is not final, this defect may be argued by the participant on appeal, when in accordance with Section 89, Paragraph 2 of the Code of Administrative Procedure appellate administrative body shall review the compliance of the challenged decision and relating proceedings with the legal regulativ ex officio. In the case of an unlawful final decision the unlawfulness can be argued in the complaint against a decision of an administrative authority (Code of Administrative Justice, 2002, § 65); further review proceedings may be initiated in accordance with Section 94 et seq. of the Code of Administrative Procedure; however, it can be initiated only ex officio (the participant may only apply the motion to commence proceedings). 


\section{Nullity of an administrative decision}

The nullity is a consequence of the most serious defects of administrative decisions. The nullity is based on the concept of "nothingness", which we understand as nonentity, nonexistence. Therefore a null decision can be defined as a non-existent one: it is an act that does not exist from the perspective of law-it is so-called "legal nullum". In the case of a null decision we can say that it is a legally irrelevant result in the activity of an administrative body. The nullity represents the most serious and also irremovable and incurable defect, therefore this defect cannot be - neither with the passage of time or otherwiseremoved or healed. The legal "quality" of something that does not exist cannot be changed; the defects of something that does not exist cannot be removed.

As the null decision does not exist from the perspective of law, it is not able to cause any public legal effects. A null administrative act is not able to affect the rights and duties of its recipients; rationally we apply the principle "quo nullum est, nulllum producit effectum" (Máša, 1972, p. 139). Null decisions are the only category of defective administrative decisions that constitute an exception to the principle of the presumption of validity and correctness of administrative acts. Therefore no one is obliged to respect the null administrative decision and follow it. On the contrary, other defective (but not null) administrative decisions are valid and until their eventual change or cancellation they have the intended legal effect.

Foreign administrative doctrines look at the nature of the defect of nullity of an administrative act very similarly. German literature clearly states that "der nichtige VA zeitigt keine Rechtswirkungen, er ist weder für den Betroffenen noch für Behörden oder Gerichte verbindlich..., die Nichtigkeit eines VA kann nicht geheilt werden" (see, e.g., Redeker \& von Oertzen, 1994, p. 188; Lehmann, 2000, p. 130). Similarly, nullity is understood in the Austrian administrative law, where the nullity of an act means that the decision has not been issued, and therefore, it cannot give rise to any legal effects (Koja, 1986, p. 521). Also, Slovak doctrine clearly states that the nullity of an act occurs when its defects have reached such an intensity that we cannot even talk about an act; such an act cannot bind its addressees and has no legal effects, respectively, in the legal sense of the word it does not exist (Cepek, 2010, p. 141).

Now back to the issue of nullity in the Czech Republic. As already mentioned, a null administrative decision is a decision which suffers from such fundamental defects that it cannot be regarded as a decision. These defects are so severe 
that they cause the legal nonexistence of such an administrative act. Crucial to determining whether it is a null act or an otherwise defective act, is the nature and character of the defects of an administrative act, which we refer to as the reasons for the nullity of the administrative decisions.

Despite its severity and irreversibility, the nullity has not been reflected in the Czech legislation very long; however, it does not mean that the nullity has been an unknown phenomenon in the Czech administrative doctrine and practice or that it has not been a part of the real performance of public administration. Defining the nature of the nullity, its reasons, as well as the process leading to the removal of non-existent act of legal sphere of affected subjects was - until 2006-left only to the doctrine and case law. A major step was the adoption of the Code of Administrative Procedure, which came into force on 1 January 2006. Already in 2003 the Code of Administrative Justice came into force, but this only briefly regulates the practice of administrative courts in relation to the null decision, and is silent as to the definition of the nature of the nullity, as well as its reasons.

From the perspective of the definition of the nullity and its reasons, Section 77 of the Code of Administrative Procedure is therefore essential, providing that:

A decision is null if an administrative body has no subject-matter jurisdiction; this rule does not apply if the decision is issued by an administrative body superior to that having subject-matter jurisdiction. Nullity shall be ascertained and declared in form of a decision by an administrative body superior to that which has issued the null decision. (\$77, Para. 1)

A decision is null which suffers from defects causing the decision to be apparently contradictory of legally of factually impracticable, or from other defects which exclude the document from being considered to be a decision of an administrative body. Nullity due to such reasons shall be declared by a court according to the Code of Administrative Justice. (§ 77, Para. 2)

The provisions of Section 77 of the Code of Administrative Procedure are relatively brief. First and foremost, it is evident that the legislator does not define the very essence of the nullity and its legal consequences (The Supreme Administrative Court, 2008c). He comes out only in silence and without any further justification of the conclusions that emerged from the administrative legal doctrine and case law. Conversely, the legal definition of reasons for the nullity of an administrative decision is positive in that it can help partly re-define the essence of the nullity. The legislation concerning the nullity and its reasons in the 
Czech Code of Administrative Procedure was greatly affected by the conclusions of German theory and legislation that distinguishes between the general ground of nullity and specific reasons of nullity. German legislation governs the grounds of nullity in Article 44 of Verwaltungsverfahrensgesetz (VwVfG, 1976, p. 1253). This provision contains mainly the so-called general clause of nullity ( $\$ 44$, Para. 1 of $\mathrm{VwVfG}$ ) and subsequently the enumeration of special reasons for the nullity, mentioned in Article 44, Paragraph 2 of VwVfG. According to the general clause, ${ }^{4}$ such administrative acts which suffer particularly serious defect are null, and this is also evident (see, e.g., The Supreme Administrative Court, 2013 or 2008c). German theory and case law is then based on the so-called Evidenztheorie, under which the defect is evident if a layman familiar with the basic facts of the case concluded that the administrative act must be non-existent (Kopp, 1983, pp. 629-631). In addition to this general clause, Article 44, Paragraph 2 of VwVfG defines six special reasons for the nullity. When considering the non-existence of an administrative act, it must be first examined whether the nullity is given by some of the special reasons of nullity and only then can we consider whether an administrative act can not be null with regard to the fulfillment of characters of the general clause. On the other hand, some foreign legislation does not contain the general clause. Only specific reasons for the nullity embody the Polish or Austrian legal order. Personally, however, I consider that legislation containing the general clause is more suitable as it is not always possible to subsume each defect under some of the special reasons of nullity.

The current Czech legislation divides the grounds of nullity into two groups on the basis of the fact of which of the public authorities have the competence to declare authoritatively the nullity of an administrative decision (whether it is the court or the superior administrative authority). Furthermore, it implies that there are specified both some special reasons for the nullity and also some indication of the general reason of nullity (i.e. the general clause).

The first reason for the nullity is de lege lata defined as the lack of subjectmatter jurisdiction - that is, a decision is null if an administrative body has no subject-matter jurisdiction to issue it. An example might be a situation in which the construction office decided instead of the tax office, or the Ministry of Justice decided instead of the Ministry of Finance. But if the decision is issued by an administrative body superior to that having subject-matter jurisdiction, such decision is not null. ${ }^{5}$

4 "An administrative act shall be invalid where it is very gravely erroneous and this is apparent when all relevant circumstances are duly considered." (VwVfG, § 44, Para. 1).

5 The lack of territorial jurisdiction does not cause the nullity. 
A decision is also null if it suffers from defects causing the decision to be apparently contradictory or legally impracticable or factually impracticable. These are further, explicitly enshrined special reasons for the nullity. An apparently contradictory decision is such decision which is meaningless, unintelligible, and we can not determine how the administrative authority decided (e.g., the administrative authority decided that the addressee has not committed an administrative offense, but at the same time the addressee is fined for this offense). A legally impracticable decision is a decision that decides on the rights of someone who does not exist or on the thing that does not exist (e.g., a person is deprived of the ownership of the house that did not exist). And factually impracticable can be a decision which requires a construction of a building in a manner that is technically impossible.

Furthermore, the Code of Administrative Procedure provides that a decision is null if it suffers from other defects which exclude the document from being considered to be a decision of an administrative body. Here we find the general clause of nullity, inspired by German legislation. The question is what defects of a decision can be subsumed under this clause. Here the administrative doctrine and case law helped us significantly and deduced a number of these reasons. Among these other reasons for the nullity we can assign particularly: the lack of competence, ${ }^{6}$ the lack of legal basis, ${ }^{7}$ the lack of collegiate body composition, ${ }^{8}$ the requirement of fulfillment of a criminal nature, ${ }^{9}$ the absolute lack of willingness of the administrative body, ${ }^{10}$ or the absolute lack of a form of an administrative decision. ${ }^{11}$

In addition to the clear and unambiguous definition of the reasons for the nullity, another key issue associated with nullity is whether, how and who should "remove" a null decision of an administrative body. At first glance, such considerations may seem pointless: if it is a "legal nothing", which does not bind anyone and has no legal effect, why is it necessary to remove such a decision by a legally formalized procedure of a legal sphere of the persons concerned? The essence of the problem lies in the fact that while a non-existent decision can not cause legal effects (de jure), de facto in many cases it can significantly

\footnotetext{
$6 \quad$ E.g., an administration body decided instead of a court.

7 Such as a situation in which an administrative body decided according to the act which has already been canceled.

8 E.g., only one official decided instead of a three-member committee.

9 This means that by the performance of such a decision a crime or administrative offense would have been committed.

10 E.g., a situation in which an official was forced to issue a decision using physical violence.

11 A decision was issued orally instead of in writing.
} 
interfere in the sphere of rights and duties of the persons concerned. Besides the obvious examples of the null acts, there may also be administrative decisions, which are apparently defective, but the determination of the kind and the nature of the defect can be very difficult not only for the addressee of the act, but often also for the administrative authority or other public authority (e.g., the court). If the addressee considers the administrative act to be non-existent, but the public authority does not, it can lead to substantial interference with the rights and duties of the recipient on the basis of non-existent act (e.g., the execution of such decision).

As mentioned above, nullity has not been regulated very long by the Czech legislation and therefore neither the administrative bodies nor the courts could deal with the null decision in the most logical way - that is, by issuing a declaratory act that would authoritatively state the nullity of the administrative decision. The competent authorities were forced to act in a manner corresponding to the limits on the exercise of public power and concurrently providing the most effective protection for the addressees concerned - therefore they had to cancel even the null acts - that is, acts that do not exist. ${ }^{12}$ The fundamental change in this practice meant the entry into force of the Code of Administrative Procedure on 1 January 2003, which expressly allowed the nullity of an administrative decision by the judgment of an administrative court. Subsequently, the Code of Administrative Procedure was adopted which, with effect from 1 January 2006, following the reasons for the nullity, regulates the jurisdiction of the courts and administrative bodies to declare the nullity of the administrative decision.

At present, the Czech legislation is based on the concept of divided competence for the declaration of nullity. This means that the competence to declare nullity is given partly to superior administrative authorities and in full (i.e. for all the reasons of the nullity) to the administrative courts. However, the superior administrative authority is empowered to declare the nullity for only one reason - for the lack of subject-matter jurisdiction. The administrative authority has this competence within the so-called proceedings to declare nullity, which is regulated by Section 78 of the Code of Administrative Procedure. It is essential that this procedure can not be initiated on the request of the addressee of the decision because the administrative authorities are given powers to ascertain and declare the nullity only ex officio, which significantly weakens the functionality of this procedure as a means of protecting a citizen before null administrative acts. A participant in proceedings may seek a declaration of nullity, for example,

12 This situation has persisted to this day, for example, in the Slovak Republic. 
in Poland, where Article 157, Section 2 of KPA (Ustawa z dnia ..., 1960) allows to declare nullity of the decision at the request of the parties, as well as ex officio. Also the German legislation allows the declaration of nullity ex officio, as well as at the request, provided that the applicant has a legitimate interest in the declaration (Kopp, 1983, pp. 649-650). On the contrary, identically with the Czech legislation, only Austrian legislation allows declaring the nullity ex officio (§ 68, Para. 4 of AVG; Allgemaines Verwaltungsverfahrensgesetz, 1991).

The fact that nullity shall be ascertained and declared ex officio anytime can be positively evaluated. The law sets no time limits for the commencement or termination of proceedings for a declaration of nullity which corresponds to a fundamental attribute of a non-existent decision: this defect cannot be removed or healed with the passage of time. Similarly, the competence to declare the nullity is not limited in time in Germany. ${ }^{13}$ If the superior administrative body concludes that the decision is actually null because of the lack of subject-matter jurisdiction, this body declares the nullity of such a decision in the form of a declaratory decision. The nullity of a decision is thus declared with the effect ex tunc - that is, it is stated that the decision was non-existent since the time of its issuance. The declaration of nullity has the same legal consequences, for example, in Poland (Art. 156 of KPA; Chróścielewski \& Tarno, 2006, p. 190). No appeal shall lie against a decision whereby an administrative body declares the nullity of a decision (§ 78, Para. 2).

In the Czech Republic, the administrative courts may declare the nullity of an administrative decision and, unlike the superior administrative authority, on all grounds of nullity. The Code of Administrative Justice allows courts to declare the nullity in the proceedings concerning a complaint against a decision of an administrative authority ( $\$ 65$ et seq.). According to Section 65 of the Code of Administrative Justice, anyone who claims that their rights have been prejudiced directly or due to the violation of their rights in the preceding proceedings by a decision of an administrative body may seek (besides the cancellation of such a decision) the declaration of its nullity. The complaint can be filed within two months after the complainant was notified of the decision, unless a special law prescribes another time limit. The filing of a complaint does not have suspensory effect, even in the case of the alleged nullity of the contested decision. ${ }^{14}$ In its review of the contested administrative decision the court proceeds from the facts

13 "The authority may ascertain invalidity at any time ex officio; it must be ascertained upon application when the person making such an application has a justified interest in so doing." (VwvfG § 44, Para. 5)

14 But at the complainant's request the court shall by a resolution award suspensory effect to the complaint. 
of the case and the legal situation existing at the time of the decision-making by the administrative authority.

Proceedings before administrative courts are governed by the dispositional principle, which means that the court shall review the contested statements of the decision within the scope of counts of charge (see The Supreme Administrative Court, 2008b). However, there are exceptions to this rule. And such an exception contains the Code of Administrative Justice in Section 76, Paragraph 2, which provides that if the court finds that the decision suffers from such faults that they cause its nullity, the court declares this nullity even without a motion. The legislation thus stands on the concept that the court must always take nullity into account (even without the applicant's motion). If the court finds the decision null, it is obliged to declare the nullity of the decision in the statement of its judgment. If the causes of the nullity concern only some part of the decision, the court declares the nullity of only that part of the decision, if it does not follow from the nature of the matter that it cannot be separated from other parts of the decision.

The possibility of a judicial declaration of nullity also exists in other countries. For example, in Poland, according to Article 145 of the Act on proceedings before administrative courts these courts shall declare the nullity of a decision, for the reasons provided for in Article 156 of KPA, or in special laws (Ochendowski, 2008, p. 323). In Germany, the declaratory complaint is relevant, provided for in Section 43 of VwGO (1991). Through this complaint you can seek the declaration of the existence or non-existence of a legal relationship or declaration of the nullity of an administrative act, if the applicant has a legitimate interest in such an early declaration (Redeker \& von Oertzen, 1994, p. 141).

\section{Conclusion}

In the Czech Republic, an administrative decision represents one of the principal forms of the realization of public administration. Therefore the Czech legislation provides for its issuance a number of requirements in relation to its content and form. However, in practice there are violations of these legal conditions and requirements and then it is a matter of a defective administrative decision. A very difficult question is then the correct identification of the type of the defect in an administrative decision. This is very important both for the recipient of such an act to choose the appropriate means of defense against him, and also for the public authorities, which may review such act or execute it. 
According to how to remedy the defective administrative acts, a distinction is made between formally defective administrative decisions, factually inaccurate decisions, unlawful decisions and, next to them, separately, null administrative decisions. To remedy each of these defects different legal means are applied but null decisions occupy a specific position: a remedy is not possible in any waythis means that such a decision can not be changed or revoked, only the nullity of decision with the effect ex tunc can be declared - that is, it is stated that the decision was non-existent since the time of its issuance. However, if such a "decision" caused damage to its addressee, the state provides compensation, based on Act No. 82/1998 Coll., on liability for damages caused by an unlawful decision of public administrative authorities, or as the result of their incorrect official procedure.

The nullity, in particular, represents the most serious and also irremovable defect of an administrative decision. As the null decision does not exist from the perspective of law, it is not able to affect the rights and duties of its recipients. The null acts, as the only category of defective administrative acts, constitute an exception to the principle of the presumption of validity and correctness of administrative acts. Therefore, a major deficiency in the Czech administrative law was that, despite its severity, nullity has not been reflected in the Czech legislation very long and the definition of the nature of the nullity, its reasons, as well as the process leading to the removal of non-existent decision of legal sphere of affected subjects was left only to the doctrine and case law. We can positively evaluate the changes that have occurred in 2003 and 2006, when the Code of Administrative Justice and the Code of Administrative Procedure were adopted.

These acts for the first time explicitly regulate the reasons of nullity and the procedure of the declaration of the nullity of administrative decisions by superior administrative bodies and administrative courts, which is a great benefit of view of legal certainty of an addressee of the decision as well as of other, third persons. However, we also point out some deficiencies in the current legislation. First, the very essence of the defect of nullity still has not been explicitly defined by the law. In this aspect, it would be appropriate for the Czech legislation, inspired from the German legislation, which expressly and unambiguously provides that a null decision has no legal effect. ${ }^{15}$ Second, the Code of Administrative Procedure defines the reasons of nullity often in vague legal terms, which complicates the interpretation and application of this institution in practice. In this regard, proper and lawful decisions of administrative bodies, in particular,

15 “An administrative act which is invalid shall be ineffective." (VwVfG, § 43, Para. 3) 
requires a good knowledge and acceptance of case law of administrative courts, which - in the context of decision making - these terms professionally and appropriately interpret. Finally, we can question the correctness of the fact that a superior administrative authority may declare the nullity only for one reason and only ex officio, which is a significant difference and limitation in the competence compared to the administrative courts. Again, this is where the Czech legislation should be changed, again, following the example of Polish and German legislation, to enable a superior administrative authority to declare the nullity of all reasons, both ex officio and upon the request of the participants.

Finally, I would like to add that not only null administrative decisions, but also other types of defective decisions represent a wholly undesirable phenomenon, which represents a fundamental conflict with the basic principles of the socalled "good governance", which should be a service to all citizens. Therefore, administrative bodies should also avoid even those "less serious" defects in their decision-making activities, because it is essential for the principle of legal certainty and legitimate expectations of the citizens in relation to public authority and its functional and legal performance in any democratic state governed by the rule of law. However, these defects are not as fatal as in the case of nullity and therefore the current legal possibilities of their remedy (in a form of a correction, modification or cancellation) are adequate and sufficient.

JUDr. Kateřina Frumarová, $\mathrm{PhD}$ has been working as assistant professor at the Department of Administrative Law and Financial Law of Law Faculty of Palacký University in Olomouc in the Czech Republic since 2000, and from 2013 until today in the position of head of this department. She is also a member of the Scientific Council and of the Board of Dean of the Law Faculty of Palacky University. She has written several monographs (e.g., The Protection against the Unlawlful Inactivity of Public Administration or The Nullity of an Administrative Decision) and she is the author of nearly fifty scientific articles and papers. 


\section{References}

Allgemeines Verwaltungsverfahrensgesetz, BGB1 No. 51/1991.

Adamiak, B. \& Borkowski, J. (2009), Postepowanie administracyjne $i$ sadovoadministracyjne [Administrative proceedings and administrative justice], Warszawa: LexisNexis.

Cepek, B. (2010), 'Účinky rozhodnutia vydaného v správnom konaní v nadväznosti na problematiku nulitnosti individuálneho správneho aktu' [Legal effects of null administrative decision], in V̌́eobecné správne konanie. Zborník z medzinárodnej vedeckej konferencie 8.-9. Októbra 2009 Častá-Papiernička, Bratislava: Univerzita Komenského v Bratislave, Právnická fakulta, pp. 140-146.

Chavrier, A. L.; Delamarre, M. \& Paris, T. (2010), Leçons de droit administratif general [Book of general administrative law], Paris: Ellipses.

Chróścielewski, W. \& Tarno, J. P. (2009), Postępowanie administracyjne $i$ postepowanie przed sadami administracyjnymi [Administrative proceedings and administrative justice], Warszawa: LexisNexis.

Code of Administrative Justice (2002), Act of $21^{\text {st }}$ March 2002, No. 150/2002 Coll. Code of Administrative Procedure (2004), Act of 24 ${ }^{\text {th }}$ June 2004, No. 500/2004 Coll.

Commission of the European Communities v. BASF AG, etc. [1994], Judgment of the Court of Justice of EU in Case Commission v. BASF AG, etc., ECR I-2555, C-137/92 P.

Commission of the European Communities v. Greece [1988], Judgment of the Court of Justice of EU in Case Commission v. Greece, ECR 2875, 63/87.

Constitution of the Czech Republic (1992), Ústavní soud České republiky, No. 1/1993 Coll., 16 December 1992.

Council of Europe (1996), The Administration and You. Principles of administrative law concerning the relations between administrative authorities and private persons. A handbook, Strasbourg: Council of Europe.

Craig, P. (2006), EU Administrative Law, Oxford: Oxford University Press. http:// dx.doi.org/10.1093/acprof:oso/9780199296811.001.0001

Hendrych, D. et al. (2012), Správní právo: Obecná část [Administrative law. General part], Praha: C. H. Beck.

Hoetzel, J. (1934), Československé správní právo. Část všeobecná [Czechoslovak administrative law. General part], Praha: Melantrich.

Hofmann, H. C. H.; Rowe, G. C. \& Türk, A. H. (2011), Administrative Law and Policy of the European Union, Oxford: Oxford University Press. http://dx.doi. org/10.1093/acprof:oso/9780199286485.001.0001

Horáková, M. et al. (2011), Správní řizení v zemích EU. Velká Británie, Francie, Německo a Itálie [Administrative proceedings in EU countries. Great Britain, France, Germany and Italy], Praha: Linde Praha. 
Kędziora, R. (1989), Ogólne postępowanie administracyjne [General administrative proceedings], Warszawa: PWN.

Koja, F. (1986), Allgemeines Verwaltungrecht [General administrative law], Wien: Manzsche Verlags- und Universitätsbuchhandlung.

Kopp, F. O. (1983), Verwaltungsverfahrensgesetz [Code of administrative procedure], München: C. H. Beck'sche Verlagsbuchhandlung, pp. 629-631.

Lehmann, P. (2002), Allgemeines Verwaltungrecht [General administrative law], Brühl: Bundesakademie für öffentliche Verwaltung im Bundesministerium des Innern.

Máša, M. (1972), 'K otázce tzv. nicotných aktů' [To the issue of so-called defective acts], Správní právo, no. 3, pp. 137-150.

Mazanec, M. (1996), Správní soudnictví [Administrative justice], Praha: Linde.

Ochendowski, E. (2001), Prawo Administracyjne. Cześć ogólna [Administrative law. General part], Toruń: Dom Organizatora.

Potash, P. \& Hašanová, J. (2012), Správny poriadok. Komentár [Code of Administrative Procedure. Commentary], Bratislava: C. H. Beck.

Potěšil, L. (2006), 'Napadnutelná vadná správní rozhodnutí' [Actionable defective administrative decisions], Právní rádce, vol. XIV, no. 12, pp. 49-52.

Průcha, P. (2013), Správní ř́d s poznámkami a judikaturou [Code of Administrative Procedure with commentary and case-law], Praha: Leges.

Redeker, K. \& von Oertzen, H.-J. (1994), Verwaltungsgerichtsordnung. Kommentar, [Code of administrative justice. Commentary.], Stuttgart: Kohlhammer Stuttgart.

Resolution of the Presidium... (1993), Resolution of the Presidium of the Czech National Council of 16 December 1992 on the declaration of the Charter of fundamental rights and freedoms as a part of the constitutional order of the Czech Republic, No. 2/1993 Coll.

Schønberg, S. J. (2000), Legitimate Expectations in Administrative Law, Oxford: Oxford University Press. http://dx.doi.org/10.1093/acprof:oso/9780198299479.001.0001

Schwarz, B. (2006), French Administrative Law and the Common-Law World, New Jersey: The Lawbook Exchange, Ltd.

Shell International Chemical Company v. Commission of the European Communities [1992], Judgment of the Court of Justice of EU in Case Shell International Chemical Company v. Commission of the European Communities, ECR II-00757, T-11/89.

Singh, M. P. (2001), German Administrative Law in Common Law Perspective, Berlin: Springer. http://dx.doi.org/10.1007/978-3-662-07456-5

Sládeček, V. (2013), Obecné správní právo [General administrative law], Praha: Wolters Kluwer ČR.

Skulová, S. et al. (2012), Správní právo procesní [Procedural administrative law], Plzeň: Aleš Čeněk.

The Supreme Administrative Court (2003), Judgment of the Supreme Administrative Court of the Czech Republic of 24. 9. 2003, no. 7, A 547/2002-24. 
- (2004a), Judgment of the Supreme Administrative Court of the Czech Republic of 22. 1. 2004, no. 4, Azs 55/2003-51.

- (2004b), Judgment of the Supreme Administrative Court of the Czech Republic of 30. 11. 2004, no. 3, As 24/2004-79.

- (2006), Judgment of the Supreme Administrative Court of the Czech Republic of 16. 2. 2006, no. 6, Ads 2/2005-95.

- (2007), Judgment of the Supreme Administrative Court of the Czech Republic of 20. 11. 2007, no. 8, Afs 114/2006-54.

- (2008a), Judgment of the Supreme Administrative Court of the Czech Republic of 31. 3. 2008, no. 8, Ans 3/2008-61.

(2008b), Judgment of the Supreme Administrative Court of the Czech Republic of 30. 4. 2008, no. 1, As 29/2008-50.

(2008c), Judgment of the Supreme Administrative Court of the Czech Republic of 13. 5. 2008, no. 8, Afs 78/2006-74.

(2009), Judgment of the Supreme Administrative Court of the Czech Republic of 25. 3. 2009, no. 2, As 91/2008-85.

- (2010), Judgment of the Supreme Administrative Court of the Czech Republic of 30. 9. 2010, no. 7 As 71/2010-97

- (2011), Judgment of the Supreme Administrative Court of the Czech Republic of 16. 6. 2011, no. 7, As 23/2011-82.

- (2013), Resolution of Supreme Administrative Court of the Czech Republic of 12. 3. 2013, no. 7, As 100/2010-65.

Ustawa z dnia... (1960), Ustawa z dnia 14 czerwca 1960 r. Kodeks postepowania administracyjneg, Dz.U. 1960, no. 30, poz. 168.

Vrabko, M. et al. (2012), Správne právo hmotné. V̌̌eobecná čast’ [Substantive administrative law. General part], Bratislava: C. H. Beck.

VwGO (1991), Verwaltungsgerichtsordnung vom 19. März 1991, BGB1. I, p. 212. VwvfG (1976), Verwaltungsverfahrensgesetz vom 25. Mai 1976, BGB1. I, p. 1253.

Wade, W. \& Forsyth, Ch. (2009), Administrative Law, Oxford: Oxford University Press. 